\title{
Efek Penambahan Sari Bunga Rosella (Hibiscus sabdariffa L.) Terhadap Kualitas Selai Lembaran Dami Nangka (Artocarpus heterophyllus)
}

\author{
Veronica Angga Puspita ${ }^{1}$ dan Tatang Sopandi ${ }^{2}$ \\ 1) Mahasiswa Prodi Biologi F. MIPA Universitas PGRI Adi Buana Surabaya \\ 2) Staf Pengajar Prodi Biologi F. MIPA Universitas PGRI Adi Buana Surabaya
}

\begin{abstract}
Straw from jackfruit so far is still considered a waste that is still thrown away by most people and even often becomes a problem that can pollute the environment. Jackfruit straw contains many of the same substances as fruit flesh such as protein, crude fiber, sugar and so on. Jackfruit straw has pectin which can be used as raw material in making jam. In making jam, fruits that have high acidity are also needed. Rosella contains vitamin $C$ and flavonoids in the form of antosanin which can be used as flavor enhancers and natural dyes. The aim of this study was to determine the addition of rosella flower concentration that produced the best jackfruit straw jam based on the level of panelist preference (texture, color, taste), anthocyanin content, vitamin $C$ content. This study used a completely randomized design with 5 treatments consisting of concentrations $0 \%, 10 \%, 20 \%, 30 \%$ and $40 \%$ with 5 repetitions. Analysis carried out by ANOVA test, if there is an effect of giving rosella juice then it will be followed by Duncan's test. The results showed that the addition of $40 \%$ roselle flower extract affected the level of preference for texture, color and taste. The addition of $40 \%$ has the highest total anthocyanin content of $45.22 \mathrm{mg} / 100 \mathrm{~g}$ and the total content of vitamin $C$ in jackfruit straw sheet jam is 35.11 ppm.
\end{abstract}

Keyword : Jam sheet, jackfruit, rosella essence, levels of pleasure, anthocyanin contains, vitamin C contains.

\section{Pendahuluan}

Pengolahan buah untuk memperpanjang masa simpan sangat penting. Buah dapat diolah menjadi berbagai bentuk minuman seperti anggur, sari buah dan sirup juga makanan lain seperti selai, manisan, dodol, keripik, dan sale. Salah satu alternatif yang dapat dipilih dalam mengolahnya yaitu selai.Selai merupakan produk makanan yang berbentuk setengah padat dan dibuat dari campuran gula dan buah(Dewi ,2010).
Dalam pembuatan selai buah harus menggunakan buah yang mengandung pektin dan asam yang cukup untuk menghasilkan selai yang baik (Desrosier,2008).Pektin digunakan sebagai pembentuk jeli, selai, pengental (Marcia, 2004). Penambahan pektin dalam selai harus sesuai, bila terlalu rendah tidak akan dapat membentuk selai, begitu juga bila pektin terlalu tinggi maka selai yang terbentuk menjadi sangat kental (Dewi ,2010). Pembentukan gel pada pembuatan selai dapat dicapai jika kandungan 
pektin yang digunakan 0,75-1,5\% (Deman , 1989). Pektin yang digunakan untuk pembuatan selai selama ini berasal dari penambahan pektin yang telah diekstrak.Kelemahan dari pektin tersebut adalah harganya yang cukup mahal yaitu 250.000/kg, tidak semua ekstrak pektin sesuai atau dapat digunakan pada selai.Oleh karena itu perlu dicari sumber pektin yang lebih murah dan dapat sesuai untuk pembuatan gel pada selai.Adanya hal tersebut memungkinkan dami nangka digunakan sebagai bahan dalam pembuatan selai lembaran.Tanaman nangka merupakan buah-buahan yang banyak digemari karena rasanya lezat dan manis. Buah nangka terdiri atas daging buah, biji, jerami/dami, dan kulit.Biji dan jerami atau dami nangka merupakan bagian dari buah nangka yang masih kurang dimanfaatkan.

$$
\text { Dami dari buah nangka }
$$
selama ini masih dianggap sebagai limbah yang masih dibuang begitu saja oleh sebagian besar masyarakat dan bahkan sering menjadi masalah yang dapat mencemari lingkungan. Walaupun sering dianggap limbah, ternyata jerami buah nangka masih banyak mengandung zat-zat yang sama dengan daging buahnya seperti protein, serat kasar, gula dan sebagainya (Sumarni, 2011).

Dami nangka juga memiliki kandungan serat yang cukup tinggi serta kandungan pektin yang merupakan salah satu syarat dalam pembuatan selai. Jerami nangka memiliki sifat fisik maupun kimiawi yang diduga hampir sama dengan buahnya. Kandungan serat kasar jerami nangka sekitar 1,94\% sementara daging buahnya adalah $1,58 \%$ (Novandrini,2003). Kandungan serat makanan total jerami nangka muda adalah $76,58 \%$ bk (berat kering) (Novandrini,2003). Dami nangka merupakan salah satu buah yang memiliki kandungan pektin yang cukup tinggi yakni 2,38\%.

Dalam pembuatan selai, buah-buahan yang memiliki keasaman tinggi ( $\mathrm{pH}$ sekitar 3,0) juga diperlukan (Muryanti,2011). Dengan penambahan sari rosella dapat memberikan keasaman yang sesuai dengan persyaratan tersebut, yakni sebesar $13 \%$ (Maryani dan Kristina,2008).

Tanaman rosella merupakan jenis tanaman anggota Malvaceae yang populer di kalangan masyarakat karena banyak digunakan sebagai minuman penyegar, memiliki aroma yang khas, mengandung asam sitrat dan malat, dan memiliki warna alami yang menarik (Maryani dan Kristiana, 2008). Bunga rosella dapat dijadikan bahan baku selai karena warnanya yang merah menyala dan dapat menghasilkan selai yang menyehatkan dan berwarna cantik (Sutomo, 2009). Selain rasanya enak, kelopak bunga ini memiliki efek farmakologis yang cukup lengkap seperti diuretic (melancarkan air seni) onthelmintic (membasmi cacing), antibacteri, 
antiseptic,anti radang, menurunkan panas, meluruhkan dahak, menurunkan tekanan darah, mengurangi kekentalan darah dan menstimulasi gerak peristaltic usus. Daun, buah dan bijinya juga berperan sebagai diuretic, anti sariawan dan Pereda nyeri.

$$
\text { Rosella }
$$

(Hisbiscus

sabdariffa L.) juga memiliki kandungan vitamin $\mathrm{C}$ dan flavonoid yang berpotensi sebagai antioksidan alami. Kandungan antosianin pada rosella selain berfungsi sebagai pewarna alami juga memiliki antioksidan (Mardiah , 2015). Rosella juga ditujukan untuk memperbaiki warna selai lembaran dan pengatur suasana $\mathrm{pH}$ selai lembaran. Penambahan rosella akan memperbaiki $\mathrm{pH}$ dari selai lembaran dimana hal ini dibutuhkan oleh pektin untuk membentuk gel yaitu sebesar 3,1-3,5. Suasana asam yang bermuatan positif akan menyebabkan pektin yang bermuatan negatif menjadi netral sehingga dapat membentuk struktur gel yang kokoh dan stabil (Belitz , 1987).

Pada beberapa penelitian yaitu penelitian yang telah dilakukan oleh Lauw,S.(2017) bahwa pemberian rosella pada selai lembaran apel rome memberikan pengaruh pada perbaikan rasa dan warna selai lembaran. Pada penelitian Muryanti (2011), selai rosela memiliki kadar vitamin $\mathrm{C}$ sebesar 91,95 mg/100g bahan. Sedangkan pada penelitian Mutiara Y. (2012) mengungkapkan bahwa pada pembuatan selai lembaran dami nangka dengan belimbing wuluh tidak berpengaruh pada tingkat kesukaan (uji skor) terhadap warna, aroma dan rasa pada selai lembaran, tetapi berpengaruh terhadap total kadar vitamin $\mathrm{C}$ dan PH pada selai lembaran. Dan pada penelitian Sri W. (2017), mengungkapkan bahwa pada pembuatan selai campuran dami nangka dan sirsak mempengarui derajat kesaman sebanyak 4,66\%, pada uji sensori (deskripsi) menunjukkan warna kunng, rasa dami nangka dan sirsak, tekstur lembut dan beraroma dami nangka dan sirsak.Sehubungan dengan hal tersebut penggabungan dami nangka dan sari rosella bertujuan untuk memenuhi syarat $\mathrm{PH}$, pektin dan warna selai. Adanya Pektin pada dami nangka dapat membantu pembentukan tekstur selai lembaran dan adanya penambahan sari rosella dapat memberikan $\mathrm{PH}$ selai dan membantu memperbaiki warna dari selai lembaran.

Penelitian ini bertujuan untuk mengetahui pengaruh penambahan sari bunga rosella (Hisbiscus sabdariffa L.) terhadap karakteristik organoleptic(warna, rasa, tekstur), kandungan vitamin $\mathrm{C}$ dan kandungan antosianin selai lembaran dari dami nangka (Artocarpus heterophyllus). Alasan memanfaatkan dami atau jerami nangka adalah karena dami nangka juga memiliki kandungan pektin yang berpotensi sebagai bahan dasar pembuatan selai.Serta dengan 
penambahan sari bunga rosella yang memiliki kandungan vitamin $\mathrm{C}$, antosianin dan antioksidan serta sebagai penanambah asam untuk pembuatan selai.

\section{Metode Penelitian}

Penelitian ini merupakan penelitian eksperimen yang dilakukan untuk mencari pengaruh variable tertentu terhadap variable yang lain dalam kondisi terkontrol secara ketat. Rancangan penelitian yang dipakai adalah rancangan acak lengkap (RAL) dengan yang diulang 5 kali. Perlakuan terdiri atas 5 takaran pemberian bunga rosella yaitu $0 \%, 10 \%, 20 \%, 30 \%, 40 \%$.

\section{Pembuatan Sari Bunga Rosella}

Dalam penelitian ini akan dilakukan dengan pembuatan sari bunga rosella lalu dilanjutkan dengan pembuatan bubur dami nangka dan terakhir dilakukan pembuatan selai lembaran. Rosella yang digunakan berasal dari $\mathrm{CV}$. Indofun herbal solution dipilih bunga rosella yang masih segar dan tidak ada cacat ,dilakukan pencucian yang bertujuan untuk menghilangkan kotoran yang melekat pada rosella setelah itu ditiriskan, kemudian diblanching dengan suhu $100^{\circ} \mathrm{C}$ selama 2 menit lalu didinginkan. Setelah dingin, rosella dilumatkan/dihaluskan dengan blender hingga halus dengan perbandingan air 1:5, setelah itu rosella dipisahkan ampas dan sarinya, kemudian filtras/hasil penyaringan disimpan dengan suhu $4^{\circ} \mathrm{C}$ sampai akan digunakan.

\section{Pembuatan Bubur Dami Nangka}

Pembuatan bubur, dami nangka diperoleh dari penjual dipasar sepanjang, dipilih dami nangka yang matang dan teksturnya masih bagus, kemudian dami nangka dicuci dengan air dan dipotong kecil-kecil untuk memudahkan proses penghancuran,dami nangka setelah di potong kemudian diblanching pada suhu $100^{\circ} \mathrm{C}$ selama 15 menit setelah itu didinginkan. Setelah itu dilakukan penimbangan sesuai dengan perlakuan yang akan dilakukan, penghancuran dami nangka dilakukan dengan penambahan air 2:1, pada proses penghancuran/penghalusan dami nangka juga dilakukan dengan penambahan perlakuan rosella $0 \%$, $10 \%, 20 \%, 30 \%, 40 \%$.

\section{Pembuatan Selai Lembaran}

Pembuatan lembaran selai, bubur dami nangka yang telah diberi perlakuan dimasak dengan diberi pembahan gula $45 \%$, agar $1 \%$, dan HPMC 0,6\%. Pemasakan dilakukan dengan api kecil hingga sedang, suhu diatur agar bertahan pada $80-90^{\circ} \mathrm{C}$ sambal tetap diaduk tujuan pemanasan ini untuk menghomogenkan seluruh bahan.

Selanjutnya adonan selai dimasukkan kedalam cetakan yang dilapisi dengan plastik tahan panas, lalu diratakan dengan penggaris dan disimpan dengan suhu ruang 25$28^{\circ} \mathrm{C}$ selama 24 jam. Setelah dilakukan penyimpanan 24 jam lembaran selai diuji karakteristik 
organoleptic (warna, rasa, tekstur), uji kandungan antosianin dan kandungan vitamin $\mathrm{C}$.

\section{Karakteristik Organoleptik (Warna, Rasa, Tekstur) Selai Lembaran Dami Nangka}

Dalam uji karakteristik organoleptic warna, rasa, tektur dilakukan dengan metode uji hedonic oleh 15 panelis amatir yang tidak buta warna, memiliki ambang rasa $1 \%$ gula merupakan mahasiswa dari beberapa jurusan di Universitas PGRI Adi Buana Surabaya.Panelis diminta untuk menilai warna, rasa dan tektur selai lembaran dengan menggunakan standar linked yaitu 1 = sangat tidak suka, $2=$ tidak suka, $3=$ netral, $4=$ suka, $5=$ sangat suka.

\section{Total Antosianin Selai Lembaran Dami Nangka}

Total Antosianin $=\frac{A b s o r b a n s i}{\varepsilon \times L} \times M W \times \frac{V}{W t} \times D F$

Analisis total antosianin menggunakan metode $\mathrm{pH}$ differential (perbedaan $\mathrm{pH}$ ). Pengukuran dilakukan pada $\mathrm{pH} 1$ dan 4.5 menggunakan buffer $\mathrm{KCl}$ dengan $\mathrm{pH} 1$ dan buffer potasium asetat dengan $\mathrm{pH}$ 4,5.larutan pada $\mathrm{PH}$ yang berbeda tersebut diukur serapannya menggunakan spektrofotometer UV-Vis pada panjang gelombang $520 \mathrm{~nm}$ dan 700 $\mathrm{nm}$. Kandungan total antosianin dihitung menggunakan perhitungan dengan koefisien ekstingsi molar $(\varepsilon)$ sebsesar 449,2, seperti berikut :
Keterangan:

$\mathrm{A}:\left(\mathrm{A}_{510}-\mathrm{A}_{700}\right) \mathrm{pH} 1,0-\left(\mathrm{A}_{510}-\right.$ $\left.\mathrm{A}_{700}\right) \mathrm{pH} 4,5$

$\varepsilon$ : koefisien ekstenting molar sebesar 29.600

MV : berat molekul Sianidin-3elukosida $(449,2$ $\mathrm{g} / \mathrm{mol})$

$\mathrm{Vd}$ : volume akhir pengenceran

Wt :berat bahan (g)

L :Tebal Kuvet $1 \mathrm{~cm}$

DF :factor pengencer

\section{Total Vitamin C Selai Lembaran Dami Nangka}

Penentuan kadar vitamin c dengan metode spektrofotometri. Menggunakan spektrofotometer UV-Vis akan didapatkan data berupa panjang gelombang maksimal dan absorbansi. Pengambilan data dimulai dengan membuat deret larutan standart untuk menentukan kurva kalibrasi larutaan standart . Dari deret larutan standart tersebut, kemudian diukur absorbansinya pada panjang gelombang maksimum yang didapat. Panjang gelombang optimum dengan menggunakan spektrofotometer Uv-Vis dilakukan dengan larutan standart asam askorbat pada rentang 200-400 nm.

Setelah mendapat panjang gelombang yang memiliki nilai absorbansi terbaik, kemudian dicari nilai absorbansi pada standart baku dan sampel. Nilai absorbasi dalam sampel digunakan untuk mencari persamaan regresi. Setelah mendapat persamaan regresinya, dilakukan perhitungan kadar 
vitamin $\mathrm{C}$ dengan memasukkan nilai absorbansi sampel kedalam rumus persamaan regresi.

\section{Metode Analisis Data}

Data yang diperoleh dari uji organoleptik (rasa, warna, dan tekstur), uji total antosianin dengan metode $\mathrm{pH}$-differential dan uji total vitamin $\mathrm{C}$ dianalisa dengan uji ANOVA satu arah pada $\alpha=5 \%$ jika ada pengaruh pemberian sari rosella maka akan dilanjutkan dengan uji Duncan., uji Duncan.

\section{Hasil Dan Pembahasan}

\section{Karakteristik organoleptik tekstur selai dami nangka dengan penambahan sari bunga rosella}

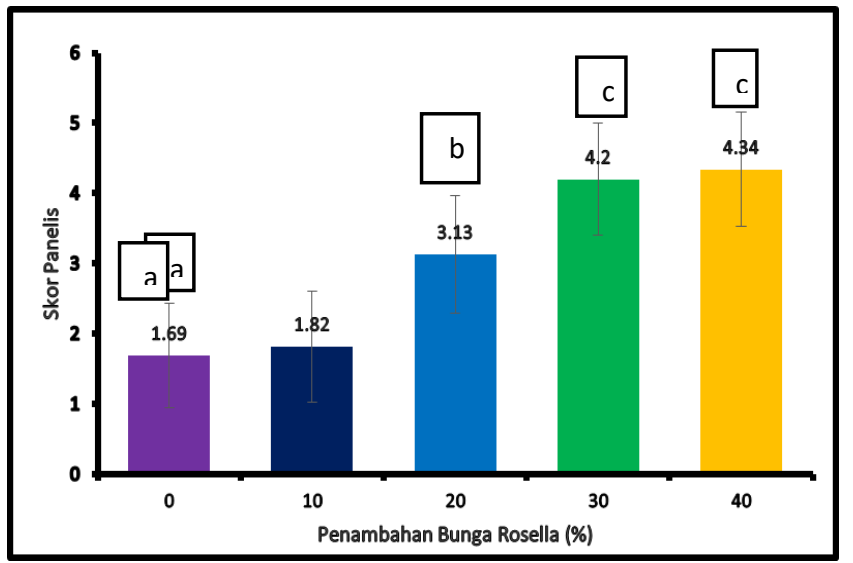

Gambar 1. Skor Panelis Tekstur Selai Dami Nangka dengan Penambahan Sari Bunga Rosella

Hasil penelitian pada gambar 5.1 menunjukkan bahwa penambahan bunga rosella pada selai lembaran dami nangka berpengaruh signifikan $(\mathrm{P}<0.05)$ terhadap tekstur. Tekstur selai lembaran dami nangka yang diberi perlakuan $0 \%$ penambahan bunga rosella $(1.69 \pm 0.75)$ tidak berbeda signifikan $\quad(\mathrm{P}<0,05) \quad$ dengan perlakuan $10 \%(1.82 \pm 0.79)$ tetapi signifikan $(\mathrm{P}<0,05)$ lebih rendah dari perlakuan $20 \%(3.13 \pm 0.84)$, $30 \%$ (4.20 \pm 0.80$)$, dan $40 \%$ (4.34 \pm $0.81)$. Tekstur selai lembaran dami nangka perlakuan $20 \%$ penambahan bunga rosella signifikan $(\mathrm{P}<0,05)$ lebih rendah terhadap tekstur $30 \%$ dan $40 \%$ penambahan bunga rosella. Dan tekstur selai lembaran dami nangka pada perlakuan 30\% penambahan bunga rosella tidak berbeda signifikan $(\mathrm{P}<0,05)$ terhadap perlakuan $40 \%$ penambahan bunga rosella pada selai lembaran dami nangka .

Hasil penelitian mengindikasi bahwa penambahan bunga rosella berpengaruh terhadap tektur pada selai lembaran dami nangka. Penambahan bunga rosella berpengaruh terhadap kadar air pada 
selai lembaran. Peningkatan kesukaan panelis terhadap tekstur selai dami nangka dengan penambahan sari bunga rosella disebabkan oleh bunga rosella mengurangi kadar pektin. Menurut Hasbullah (2001), Penambahan bunga rosella dapat menghasilkan tekstur yang lembut pada selai. Menurut Budiman (2017), kadar pektin yang tinggi akan menurunkan kadar air dan meningkatkan kekerasan tekstur pada selai lembaran dami nangka.

\section{Karakteristik organoleptik warna selai dami nangka dengan penambahan sari bunga rosella}

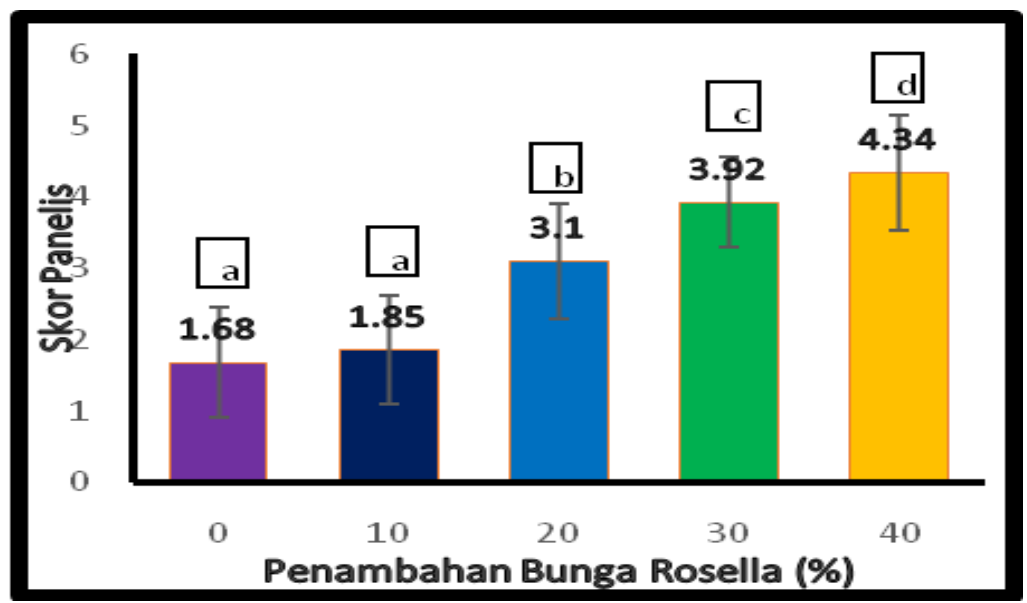

Gambar 2. Skor Panelis Warna Selai Dami Nangka dengan Penambahan Sari Bunga Rosella

Hasil penelitian pada gambar 5.2 menunjukkan bahwa penambahan bunga rosella pada selai lembaran dami nangka berpengaruh signifikan $(\mathrm{P}<0,05)$ terhadap warna. Warna pada selai lembaran dami nangka yang diberi perlakuan $0 \%$ penambahan bunga rosella $(1.68 \pm 0.77)$ tidak berbeda signifikan $(\mathrm{P}<0,05)$ dengan perlakuan $10 \%$ penambahan bunga rosella $(1.85 \pm 0.76)$ tetapi signifikan $(\mathrm{P}<0,05)$ lebih rendah dari perlakuan $20 \%(3.1 \pm 0.81), 30 \%$ (3.92 \pm 0.63$)$, dan $40 \%(4.34 \pm 0.81)$.

Warna selai lembaran dami nangka dengan perlakuan $20 \%$ penambahan bunga rosella menunjukkan perbedaan signifikan $(\mathrm{P}<0,05)$ lebih rendah terhadap perlakuan $30 \%$ dan $40 \%$ penambahan bunga rosella. Dan warna selai lembaran dami nangka pada perlakuan $30 \%$ penambahan bunga rosella menunjukkan perbedaan signifikanlebih rendah $(\mathrm{P}<0,05)$ terhadap perlakuan $40 \%$ penambahan bunga rosella pada selai lembaran dami nangka .

Warna selai dami nangkapada penelitian ini meningkatkan kesukaan panelis yang disebabkan perubahan warna pada selai lembaran dami nangka 
menjadi merah.Peningkatan warna pada selai dami nagka disebabkan oleh kandungan antosianin yang berasal dari bunga rosella.Menurut Nurfaridah (2005) antosianin merupakan pigmen alami yang memberi warna merah pada seduhan kelopak bunga Rosella. Menurut Lauw (2017), berdasarkan hasil uji organoleptik warna didapatkan hasil makin tinggi proporsi rosella, selai lembaran makin disukai. Hal ini disebabkanmakin banyak rosella yang digunakan warna selai akan makin merah. Tingkat kesukaan panelis meningkat seiring dengan banyaknya penambahan kelopak bunga rosella yang memberikan penambahan warna merah pada selai dami nangka.

\section{Karakteristik organoleptik rasa selai dami nangka dengan penambahan sari bunga rosella}

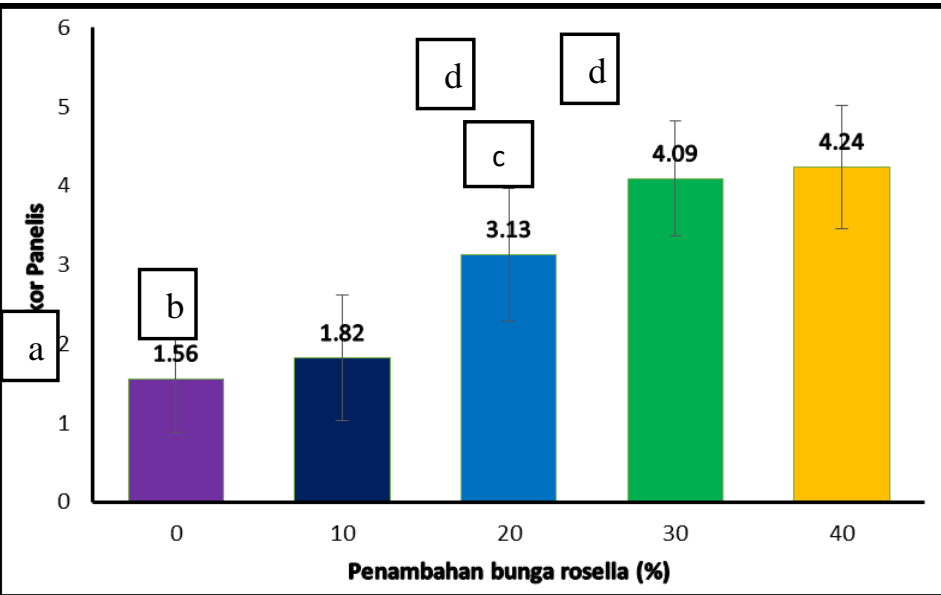

Gambar 3. Skor Panelis Rasa Selai Dami Nangka dengan Penambahan Sari Bunga Rosella

Hasil penelitian pada gambar 5.3 menunjukkan bahwa penambahan bunga rosella pada selai lembaran dami nangka berpengaruh signifikan $(\mathrm{P}<0.05)$ terhadap rasa. Rasa pada selai lembaran dami nangka yang diberi perlakuan $0 \%$ penambahan bunga rosella (1.56 \pm 0.68$)$ signifikan $(\mathrm{P}<0,05)$ lebih rendah dari perlakuan $10 \%(1.82 \pm 0.79), 20 \%$ $(3.13 \pm 0.84), 30 \%(4.09 \pm 0.73)$, $40 \%(4.24 \pm 0.78)$.
Rasa selai lembaran dami nangka dengan perlakuan $10 \%$ penambahan bunga rosella menunjukkansignifikan

$(\mathrm{P}<0,05)$ lebih rendah terhadap perlakuan 20\%, 30\% dan $40 \%$ penambahan bunga rosella. Dan rasa selai lembaran dami nangka pada perlakuan $20 \%$ penambahan bunga rosella menunjukkan perbedaan signifikan $(\mathrm{P}<0,05)$ lebih rendah terhadap perlakuan $30 \%$ dan $40 \%$ penambahan bunga rosella pada selai lembaran dami nangka . 
Rasa selai lembaran dami nangka pada perlakuan $30 \%$ penambahan bunga rosella menunjukkan tidak berbeda signifikan $\quad(\mathrm{P}<0,05)$ terhadap perlakuan $40 \%$.

Hasil penelitian ini mengindikasi bahwa bahwa penambahan bunga rosella berpengaruh terhadap rasa pada selai lembaran dami nangka.Penambahan bunga rosella memberikan rasa asam pada selai. Campuran dami nangka yang memiliki kandungan pektin dan rosella yang memiliki rasa asam serta rasa manis yang berasal dari gula menyebabkan adanya campuran rasa asam dan manis pada selai. Semakin banyak proporsi bunga rosella yang diberikan maka rasa pada selai cenderung asam.

Menurut Winarno (2008) rasa dipengaruhi oleh beberapa faktor, yaitu senyawa kimia, suhu, konsentrasi, dan intensitas dengan komponen lain. Penambahan kelopak bunga rosella memberikan rasa asam dan penambahan gula memberikan rasa manis yang disebab oleh asam organik dalam rosella seperti asam sitrat dan asam malat (Iswara, 2017).

\section{Total antosianin selai dami nangka dengan penambahan sari bunga rosella}

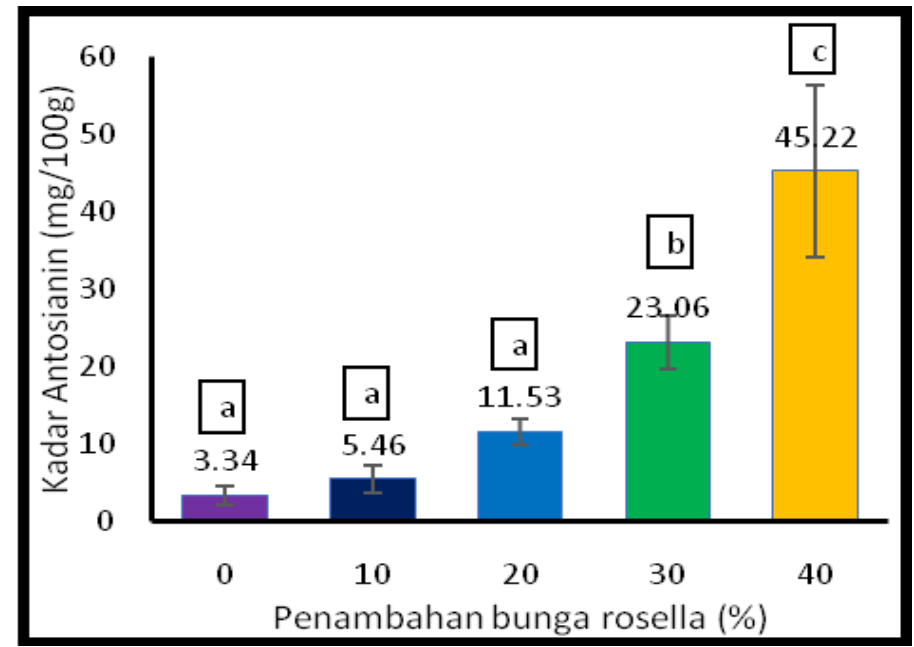

Gambar 4. Total Antosianin Selai Dami Nangka dengan Penambahan Sari Bunga Rosella

Hasil

menunjukkan bahwa penambahan bunga rosella pada selai lembaran dami nangka berpengaruh signifikan $(\mathrm{P}<0.05)$ terhadap kadar antosianin selai lembaran dami nangka. Kadar antosianin pada selai lembaran dami nangka yang diberi perlakuan $0 \%$ (3.34 \pm 1.26) tidak berbeda signifikan $\quad(\mathrm{P}<0,05) \quad$ terhadap perlakuan $10 \%(5.46 \pm 1.72)$ dan perlakuan $20 \%(11.53 \pm 1.72)$ tetapi signifikan $(\mathrm{P}<0,05)$ lebih rendah dari perlakuan $30 \%(23.06 \pm 3.46)$ 
dan 40\%(45.22 \pm 11.22). Kadar antosianin pada perlakuan $30 \%$ signifikan $(\mathrm{P}<0,05)$ lebih rendah dari perlakuan $40 \%$ penambahan bunga rosella.

Hasil penelitian ini mengindikasi bahwa bahwa penambahan bunga rosella berpengaruh terhadap total antosianin pada selai lembaran dami nangka. Penambahan bunga rosella meningkatkan kandungan antosianin pada selai dami nangka.Semakin banyak proporsi bunga rosella yang ditambahkan, total antosianin pada selai dami nangka semakin meningkat dengan ditandai perubahan warna pada selai dami nangka yang diberikan perlakuan penambahan rosella.

Menurut Nurfaridah (2005), antosianin merupakan pigmen alami yang memberi warna merah pada seduhan kelopak bunga Rosella, dan bersifat antioksidan. Total antosianin dari kelopak bunga rosella kering $\pm 502,33 \mathrm{mg} / 100 \mathrm{~g}$ (Chumsri, 2009). Penurunan antosianin dipengaruhi oleh beberapa faktor antara lain $\mathrm{pH}$, suhu, sinar, dan oksigen, serta faktor lainnya seperti ion logam. Suhu dan lama pemanasan menyebabkan terjadinya perubahan struktur dan dekomposisi pigmen sehingga terjadi pemucatan warna antosianin.Antosianin tidak stabil dalam larutan netral atau basa dan dalam larutanasam warnanya dapat memudar perlahan-lahan karena terkena cahaya (Poppy, 2013). Menurut Suzery (2010) total antosianin kelopak bunga rosella kering dengan metode maserasi $25^{\circ} \mathrm{C}$ sebesar $128,76 \mathrm{mg} / 100 \mathrm{~g}$.

\section{Total vitamin c selai dami nangka dengan penambahan sari bunga rosella}

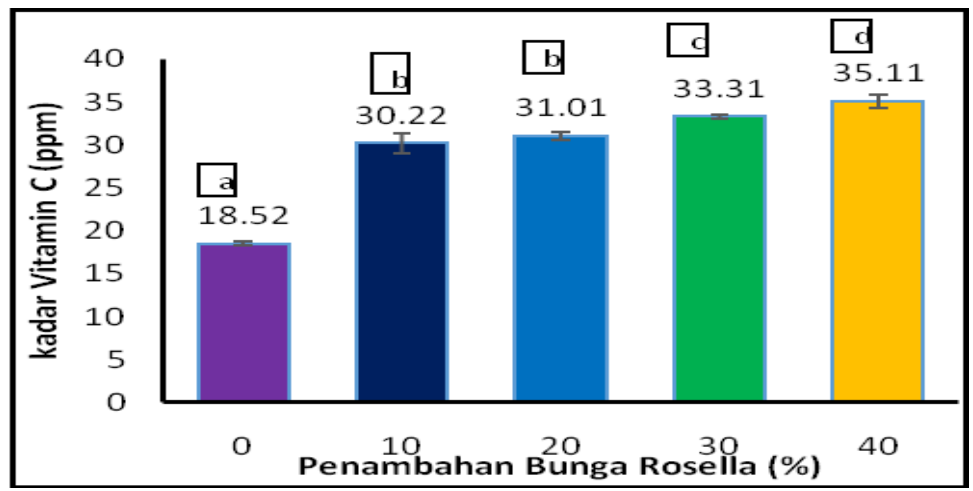

Gambar 5 Total Vitamin C Selai Dami Nangka dengan Penambahan Sari Bunga Rosella

Hasil

penelitian

menunjukkan bahwa penambahan bunga rosella pada selai lembaran dami nangka berpengaruh signifikan
$(\mathrm{P}<0.05)$ terhadap kadar vitamin $\mathrm{C}$. Kadar vitamin $\mathrm{C}$ pada selai lembaran dami nangka yang diberi perlakuan $0 \%(18.52 \pm 0.21 \mathrm{ppm})$ 
signifikan $(\mathrm{P}<0,05)$ lebih rendah dibandingkan perlakuan $10 \%$ (30.22 $\pm 1.17 \mathrm{ppm}), \quad 20 \% \quad(31.01 \quad \pm$ $0.48 \mathrm{ppm}), 30 \% \quad(33.31 \pm 0.18 \mathrm{ppm})$, dan 40\% (35.11 \pm 0.76ppm). Kadar vitamin $\mathrm{C}$ pada perlakuan $10 \%$ tidak berbeda signifikan $(\mathrm{P}<0,05)$ terhadap perlakuan $20 \%$ tetapi signifikan $(\mathrm{P}<0,05)$ lebih rendah dibandingkan perlakuan $30 \%$ dan $40 \%$ penambahan bunga rosella. Kadar vitamin $\mathrm{C}$ pada perlakuan $30 \%$ signifikan $(\mathrm{P}<0,05) \quad$ lebih rendah dibandingkan perlakuan $40 \%$.

Penambahan bunga rosella meningkatkan kadar vitamin $\mathrm{C}$ pada selai, semakin banyak penambahan rosella maka kadar vitamin $\mathrm{C}$ pada selai akan semakin meningkat.

Menurut Iswara (2017) tiap 100 gram kelopak rosella segar mengandung 260-280 miligram vitamin C, vitamin B1 dan B2. Kandungan vitamin $\mathrm{C}$ yang ada, 3 kali lipat anggur hitam, 9 kali lipat dari jeruk sitrus, 10 kali lipat lebih besar dari buah belimbing. Menurut Maryani (2008) kelopak bunga rosella mengandung $14 \mathrm{mg}$ vitamin C dalam setiap $100 \mathrm{~g}$ kelopak segar. Menurut Yuliani (2011) pada minuman jeli rosella mengandung $3,32 \mathrm{mg} / 100 \mathrm{ml}$ vitamin C.

\section{Simpulan dan Saran}

\section{Simpulan}

Hasil penelitian ini membuktikan bahwa penambahan bunga rosella dapat meningkatkan tingkat kesukaan pada tekstur selai dami nangka.Tingkat kesukaan terhadap tekstur selai dami nangka tertinggi diperoleh pada konsentrasi $40 \%$ penambahan bunga rosella.Tingkat kesukaan terhadap warna selai lembaran dami nangka meningkat dengan adanya penambahan sari bunga rosella dan iperoleh nilai tertinggi pada konsentrasi $40 \%$ penambahan bunga rosella.Tingkat kesukaan terhadap rasa selai dami nangka diperoleh nilai tertinggi pada konsentrasi $40 \%$ penambahan bunga rosella.

Penambahan bunga rosella dapat meningkatkan kandungan antosianin selai lembaran dami nangka. Kandungan antosianin tertinggi diperoleh pada konsentrasi $40 \%$ dengan total antosianin 45,22 $\mathrm{mg} / 100 \mathrm{~g}$.

Penambahan bunga rosella dapat meningkatkan kandungan Vitamin C selai lembaran dami nangka. Kandungan Vitamin $\mathrm{C}$ tertinggi diperoleh pada konsentrasi $40 \%$ dengan kadar vitamin C 35,11 ppm.

\section{Saran}

Berdasarkan hasil penelitian yang telah dilakukan, maka saran yang disampaikan yaitu penambahan bunga rosella terhadap selai lembaran dami nangka disarankan konsentrasi $40 \%$ untuk mendapatkan selai lembaran dami nangka dengan penambahan sari bunga rosella yang disukai konsumen. 
Daftar Pustaka

Armisén, R. 2009. Agar, (dalam Handbook of Hydrocolloids, G.O. Phillips and P.A. Williams, Eds.). Cambridge: Woodhead

Publishing Limited and CRC Press, LLC.87, 91-97.

Badan Standarisasi Nasional. 2008. SNI 01-3746 : 2008 Selai Buah. Jakarta : Badan Standarisasi Nasional.

Budiman. 2017. Pembuatan Selai

Campuran Buah Sirsak Dengan Buah Naga Merah. Fakultas Pertanian, Universitas Riau.

Kurniasih, D.2010.

Kajian

Kandungan Senyawa

Karotenoid, Antosianin Dan

Asam Askorbat Pada Sayuran Indigenous Jawa Barat.Departemen Ilmu Dan Teknologi Pangan, Fakultas Teknologi Pertanian, Institut Pertanian Bogor.

Direktorat Gizi Departemen

Kesehatan RI. 1996. Daftar

Komposisi Bahan Makanan.

Jakarta :Bhratara Niaga

Media.

Haliem, A. 2015. Pengaruh Konsentrasi Agar terhadap Karakteristik Fisikokimia dan Organoleptik Selai Kelapa Lembaran, Skripsi S-1, Program Studi Teknologi Pangan, Fakultas Teknologi Pertanian, Universitas Katolik Widya Mandala Surabaya, Surabaya.
Hasbullah. 2001. Teknologi Tepat Guna Agroindustri Kecil Sumatra Barat - PektinJeruk. Jakarta : Dewan Ilmu Pengetahuan, Teknologi dan Industri Sumatra Barat.

Imeson, A. 2009. Carrageenan and Furcellaran, (dalam Handbook of Hydrocolloids,G.O. Phillips and P.A. Williams, Eds.). Cambridge: Woodhead Publishing Limited and CRC Press, LLC. 169.

Imeson, A. 2010. Food Stabilisers, Thickeners, and Gelling Agents. Oxford: Blackwell Publishing Ltd. 39.

Jaya, D. 2017. Pengaruh Konsentrasi Agar terhadap Karakteristik Fisikokimia Dan Organoleptik Selai Lembaran Apel Anna dan Rosella, Skripsi S-1, Program Studi Teknologi Pangan, Fakultas Teknologi Pertanian, Universitas Katolik Widya Mandala Surabaya, Surabaya.

Lauw, S. 2017. Pengaruh Konsentrasi Agar Terhadap Karakteristik Fisikokimiadan Organoleptik Selai Lembaran Apel Rome Beauty-Rosella. Skripsi S-1, Program Studi Teknologi Pangan, Fakultas Teknologi Pertanian, Universitas Katolik Widya Mandala Surabaya, Surabaya. Mardiah. 2010. Ekstraksi Kelopak bunga Rosella dan Batang Bunga Rosella(Hibiscus sabdariffa L.) sebagai 
Pewarna Merah Alami.

Fakultas Agribisnis dan

Teknologi Pangan Jurusan

Teknologi Pangan dan Gizi Universitas Djuanda.

Margono, T. 1993. Buku Panduan Teknologi Pangan.

http://www.ristek.go.id.

Juni 2018)

Maryani, H., dan Kristiana, L. 2005.

Khasiat dan Manfaat Rosella.

Surabaya: PT.Agromedia

Pustaka.

Meiny, S. 2010. Penentuan Total

Antosianin Dari Kelopak

Bunga Rosela (Hibiscus

Sabdariffa L) Dengan Metode

Maserasi Dan Sokshletasi.

Jurnal Sains \& Matematika

(JSM), Jurusan Kimia

Fakultas MIPA, Universitas

Diponegoro Semarang.

Mutiara Y. 2012. Studi Pembuatan

Selai Campuran Dami

Nangka (Artocarpus heterophyllus) dengan

Belimbing Wuluh (Averrhoa bilimbí L.), Skripsi S-1, Fakultas Pertanian,

Universitas Andalas, Padang.

Nazmi, P. 2013. Analisis Kestabilan

Zat Pewarna Alami

Antosianin Kelopak Bunga

Rosella. Jurusan Teknologi

Hasil Pertanian, Fakultas

Teknologi Pertanian,

Universitas Jember.

Nurfaridah D. 2005. Rosella Kaya

Anti Oksidan. Departemen

Ilmu dan Teknologi Pangan

Fakultas Teknologi Pertanian,

Institut Pertanian Bogor.
Nurkhasanah. 2013. Uji

Organoleptik dan Kandungan Vitamin C pada Pembuatan Selai Belimbing Wuluh dengan Penambahan Buah Kersen dan Bunga Rosella. Skripsi. Surakarta

Universitas Mohammadiyah Surakarta.

Nussinovitch, A. 1997. Hydrocolloid Application: Gum Technology in The Food and Other Industries. London: Chapman \& Hall.

Prabandri, A. 2008. Komparasi Uji Karbohidrat pada Produk Olahan Makanan dari Tepung Terigu dan Tepung Biji Nangka (Artocarpus heterophyllus), Skripsi S-1, Jurusan Pendidikan Biologi, FakultasKeguruan dan Ilmu Pendidikan, Universitas Muhammadiyah Surakarta, Surakarta.http://eprints.ums.a c.id/2096/1/A420040051.pdf (13 Juni 2016).

Winarno F. 2008. Kimia Pangan dan Gizi, Bogor : M-Brioo Press

Yuliani, M. 2011.Studi Variasi Konsentrasi Ekstrak Rosela (Hibiscus Sabdariffa L.) Dan Karagenan Terhadap Mutu Minuman Jeli Rosela. Fakultas Pertanian, Universitas Mulawarman. 